\title{
Incidence of cancer among anthophyllite asbestos miners in Finland
}

\author{
Lauri O Meurman, Eero Pukkala, Matti Hakama
}

\begin{abstract}
A cohort of 736 male and 167 female workers of two anthophyllite mines in Finland was followed up through the Finnish Cancer Registry for cancer in 1953-91. Compared with the total cancer incidence of the east Finnish population, the men had a raised risk of total cancer (standardised incidence ratio (SIR) 1.7; $95 \%$ confidence interval (95\% CI) 1.4-1.9), mainly attributable to an excess

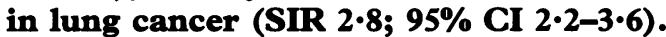
The risk of lung cancer was somewhat higher among workers classified as heavily exposed (SIR 3·2; 95\% CI $2 \cdot 4-4 \cdot 1$ ) than among those moderately exposed (SIR 2.3; 95\% CI 1.5-3.6) and the risk increased with increasing smoking and with increasing time of work with exposure. There were four cases of mesothelioma $v 0.1$ expected, all in men who smoked and had had a long and heavy asbestos exposure. Among women, a non-significant excess in total cancer (SIR 1.5; 95\% CI 0.9-2.4) was found in the subgroup with heavy exposure to asbestos. Anthophyllite asbestos seems to have high potency in the carcinogenesis of lung cancer and low potency in carcinogenesis of mesothelioma in comparison with the other types of asbestos.
\end{abstract}

(Occup Environ Med 1994;51:421-425)

University of Turku

Department of

Pathology,

Kiinamyllynkatu 8-10,

FIN-20520 Turku,

Finland

L O Meurman

Finnish Cancer

Registry, Liisankatu

21 B, FIN-00170

Helsinki, Finland

E Pukkala

University of Tampere Department of Public Health, PO Box 607, FIN-33101, Tampere, Finland

M Hakama

Correspondence to:

Eero Pukkala, Finnish

Cancer Registry, Liisankat

21 B, FN-00170 Helsinki

Finland.

Accepted for publication

25 January 1994
Numerous epidemiological studies on industrial workers exposed to asbestos have been published but there are still only a few studies of miners exposed to only one type of asbestos. $^{1-5}$ In a sparsely populated area of Finland, two anthophyllite mines were in operation between 1918 and 1975. One, Paakkila, had a dry hammer mill that produced much dust. The average fibre concentration was still 50 fibres $/ \mathrm{ml}$ in the late 1960 s. $^{6}$ Two reports on the cancer mortality of the workers of these mines have been published earlier. ${ }^{78}$

The main purpose of this study was to find out whether the biological effects of anthophyllite asbestos dust differ from the effect of other asbestos types and whether earlier reports that it does not cause mesothelioma in humans are still valid after an extended follow up period. Because the use of anthophyllite asbestos in Finland has been exceptionally high and anthophyllite fibres, as well as fibres of other types of asbestos, have often been found in lung specimens of Finnish industrial workers, ${ }^{910}$ the biological effect of anthophyllite is of national importance.

\section{Materials and methods}

Two anthophyllite asbestos mines (Paakkila and Maljasalmi) were in operation from 1918, and the salary lists had been maintained fairly completely by the mining company since 1936. The lists included the names of the workers and their periods of employment, and mostly the types of work they had carried out. The cohort analysed in this study consisted of all those who had been working for a period of at least three months in the mines between 1 January 1953 and 1 July 1967 .

The identification of the persons and follow up for death and emigration for the years 1936-67 was done manually from the Finnish national population registry and local church registrars. ${ }^{7}$ A further follow up for death and emigration was done automatically in the Population Register Centre from the unique personal identification number given to everybody residing in Finland since 1 January 1967.

Also the follow up for cancers through the files of the Finnish Cancer Registry was made manually for those who died before 1 January 1967 and automatically for those who had the personal identification number. The follow up for cancer started on 1 January 1953, the date when a nationwide cancer registration started in Finland. The members of the cohort who had died in 1952 or earlier were thus excluded. The calculation of personyears started three months after the beginning of work or on 1 January 1953, whichever occurred last, and ended at emigration, at death, or on 31 December 1991, whichever occurred first. There were no losses for follow up.

Meurman and coworkers had collected additional information about all except 20 asbestos mine workers who were alive on 1 July $1967 .{ }^{7}$ These data included smoking habits (duration and amount) and work history (duration, quality, and intensity of any dusty work). The working population was 
divided in this study into two subgroups: (a) "heavily exposed"-that is, those who had been at work either in the mines or the mill and (b) "moderately exposed"-that is, the rest of the personnel.

The numbers of observed cases and person-years at risk were counted, by five-year age groups, separately for five calendar periods and various categories according to the follow up time since the beginning of work. Further division was made by smoking category and analysed only for those interviewed. In these calculations, the follow up for incidence of cancer was started at the beginning of the year after the interview-that is, on 1 January 1968. Those that died before that date and the 20 persons for whom no interview data were available were excluded from these analyses.

The expected numbers of cases for total cancer and for specific cancer types were calculated by multiplying the number of personyears in each age group by the corresponding average cancer incidence in the same larger administrative unit of Finland where the mines were located (population 0.9 million) during the period of observation. The specific cancer types selected to be studied separately were cancers of the oesophagus, stomach, colon, rectum, larynx, lung, breast, female genitals, prostate, and bladder as well as cancers of the pleura or peritoneum histologically confirmed as mesothelioma. Lung cancer was studied also by histological type as recorded in the Cancer Registry files. The necropsy percentage in this cohort was about 30 .

Table 1 Details of workers in two anthophyllite asbestos mines under follow up

\begin{tabular}{|c|c|c|c|c|}
\hline \multirow{2}{*}{$\begin{array}{l}\text { Exposure } \\
\text { (minimum } \\
\text { time exposed) }\end{array}$} & \multicolumn{2}{|l|}{ Men } & \multicolumn{2}{|c|}{ Women } \\
\hline & No & Person-years & No & Person-years \\
\hline \multicolumn{5}{|l|}{ Heavy: } \\
\hline $\begin{array}{l}3 \text { months } \\
5 \text { years }\end{array}$ & $\begin{array}{l}459 \\
174\end{array}$ & $\begin{array}{r}13303 \\
3718\end{array}$ & $\begin{array}{l}98 \\
25\end{array}$ & $\begin{array}{r}2882 \\
366\end{array}$ \\
\hline \multicolumn{5}{|l|}{ Moderate: } \\
\hline $\begin{array}{l}3 \text { months } \\
5 \text { years }\end{array}$ & $\begin{array}{r}277 \\
38\end{array}$ & $\begin{array}{r}6941 \\
785\end{array}$ & $\begin{array}{l}69 \\
14\end{array}$ & $\begin{array}{r}2281 \\
309\end{array}$ \\
\hline \multicolumn{5}{|l|}{ Total: } \\
\hline $\begin{array}{l}3 \text { months } \\
5 \text { years }\end{array}$ & $\begin{array}{l}736 \\
212\end{array}$ & $\begin{array}{r}20244 \\
4503\end{array}$ & $\begin{array}{r}167 \\
39\end{array}$ & $\begin{array}{r}5163 \\
675\end{array}$ \\
\hline
\end{tabular}

To calculate the standardised incidence ratio (SIR), the observed number of cases was divided by the expected number. The statistical significance was tested by the Mantel-Haenszel $\chi^{2}$ test, on the presumption that the number of observed cases had a Poisson distribution

\section{Results}

WHOLE COHORT

There were 736 men and 167 women under follow up in the cohort. The numbers of person-years were 20244 and 5163, respectively (table 1). The mean duration of follow up of a person was thus 28 years.

During the total 39 year follow up period, 137 cases of cancer were found among men; the expected number was 82.7 (table 2 ). The SIR for those with heavy asbestos exposure was $1.7(95 \%$ confidence interval $(95 \% \mathrm{CI})$ $1 \cdot 4-2 \cdot 1)$ and for those with moderate exposure $1.6(95 \%$ CI $1 \cdot 2-2 \cdot 1)$. For lung cancer, a more increased risk was obtained for those heavily exposed (SIR $3 \cdot 2 ; 95 \%$ CI $2 \cdot 4-4 \cdot 1$ ) than for those moderately exposed (SIR $2 \cdot 3$; $95 \%$ CI 1.5-3.6). No significant differences were found between histological types (table 2). There were four cases of mesothelioma among the heavily exposed men (three in the pleura and one in the peritoneum) $v 0.06$ expected (SIR 67; 95\% CI 18-172; table 2).

There was no trend by time of follow up since first employment in any of the categories defined by the duration of exposed time. The risk ratios (RRs) among the heavily exposed men were higher among the men with at least five years of exposed time than in the total male cohort (table 3).

In the subcohort of 98 heavily exposed women there were 16 cases of cancer $v 10 \cdot 7$ expected (table 4). Most of this excess was attributable to endometrial cancer (SIR 6.8; $95 \%$ CI $2 \cdot 2-16)$. The excess was concentrated in the women with the longest follow up since first employment and oldest age groups.

INTERVIEWED COHORT

The interview information was not available

Table 2 Observed (Obs) numbers of cancer cases and standardised incidence ratios (SIRs) with 95\% confidence intervals (95\% CIs) among 736 male anthophyllite asbestos miners in 1953-91 with at least three months of exposed time, by level of the exposure

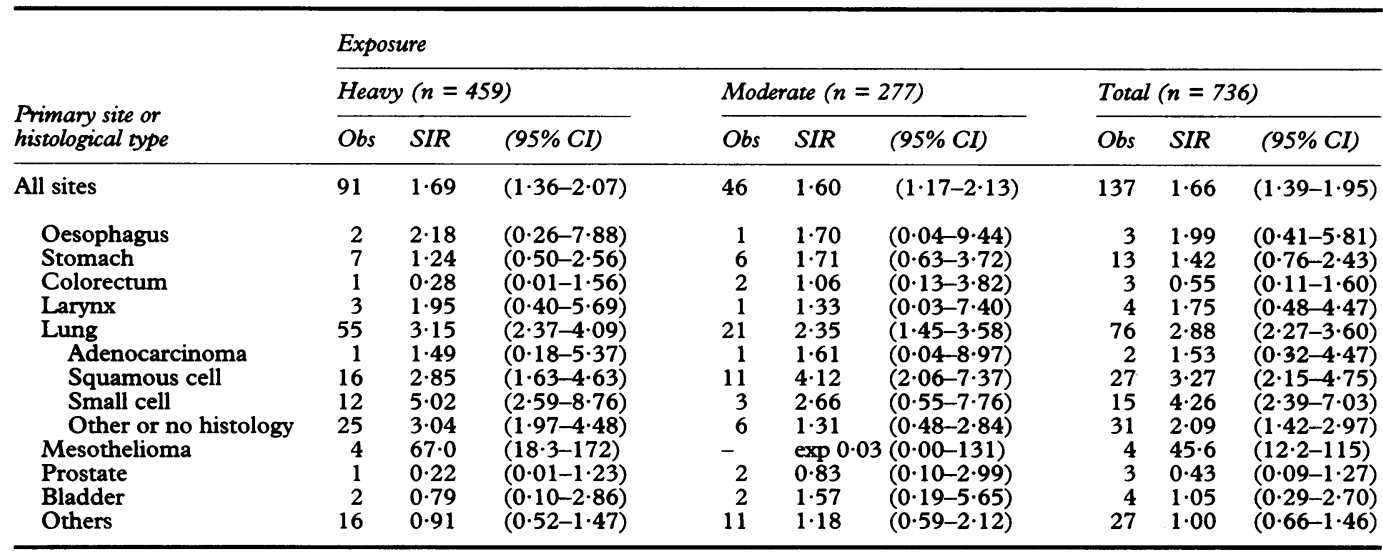


for 197 persons who died before the date of the interview (1 July 1967) and 20 other members of the cohort. The prevalence of smoking among interviewed men with heavy asbestos exposure was $86 \%$ and among men with moderate asbestos exposure $69 \%$. Only $15 \%$ of the female workers smoked.

During a follow up period from 1968 to
1991, 92 cases of cancer were observed among men in the interviewed cohort (table 5). The SIR of lung cancer systematically increased with increasing level of smoking in both exposure categories, which strongly affected the pattern of total cancer risk (table 5). All seven cases of cancers of the oesophagus, larynx, and bladder were observed

Table 3 Observed (Obs) numbers of cancer cases, and standardised incidence ratios (SIRs) with 95\% confidence intervals (95\% CIs) among 212 male anthophyllite asbestos miners in 1953-91 with at least five years of exposed time, by level of exposure

\begin{tabular}{|c|c|c|c|c|c|c|c|c|c|}
\hline \multirow[b]{3}{*}{ Primary site } & \multicolumn{9}{|c|}{ Exposure } \\
\hline & \multicolumn{3}{|c|}{ Heavy $(n=174)$} & \multicolumn{3}{|c|}{ Moderate $(n=38)$} & \multicolumn{3}{|c|}{ Total $(n=212)$} \\
\hline & Obs & SIR & $(95 \% C I)$ & Obs & SIR & $(95 \% C I)$ & Obs & $S I R$ & $(95 \% C I)$ \\
\hline All sites & 54 & $2 \cdot 70$ & $(2.02-3.51)$ & 6 & 1.59 & $(0.58-3 \cdot 46)$ & 60 & $2 \cdot 52$ & $(1 \cdot 93-3 \cdot 25)$ \\
\hline $\begin{array}{l}\text { Oesophagus } \\
\text { Stomach } \\
\text { Colorectum } \\
\text { Larynx } \\
\text { Lung } \\
\text { Mesothelioma } \\
\text { Prostate } \\
\text { Bladder }\end{array}$ & $\begin{array}{r}2 \\
2 \\
1 \\
2 \\
37 \\
4 \\
1 \\
1\end{array}$ & $\begin{array}{c}5.92 \\
0.99 \\
0.76 \\
3.60 \\
5 \cdot 54 \\
95 \cdot 8 \\
0.56 \\
1.04\end{array}$ & $\begin{array}{l}(0.72-21.4) \\
(0.12-3.56) \\
(0.02-4.25) \\
(0.44-13.0) \\
(3.90-7.63) \\
(26.1-245) \\
(0.01-3.12) \\
(0.03-5.76)\end{array}$ & $\begin{array}{l}\frac{1}{1} \\
\frac{1}{2} \\
\frac{1}{-}\end{array}$ & $\begin{array}{l}\exp 0.06 \\
2.86 \\
3.85 \\
\exp 0.10 \\
1.63 \\
\exp 0.01 \\
3.21 \\
\exp 0.19\end{array}$ & $\begin{array}{l}(0.00-61 \cdot 0) \\
(0.07-15.9) \\
(0.10-21 \cdot 4) \\
(0.00-36.2) \\
(0 \cdot 20-5 \cdot 89) \\
(0.00-407) \\
(0.08-17 \cdot 9) \\
(0.00-19 \cdot 3)\end{array}$ & $\begin{array}{r}2 \\
3 \\
2 \\
2 \\
39 \\
4 \\
2 \\
1\end{array}$ & $\begin{array}{r}5.00 \\
1.26 \\
1.27 \\
3.03 \\
4.93 \\
154 \\
0.96 \\
0.86\end{array}$ & $\begin{array}{c}(0 \cdot 61-18 \cdot 1) \\
(0 \cdot 26-3 \cdot 68) \\
(0 \cdot 15-4 \cdot 60) \\
(0 \cdot 37-10 \cdot 9) \\
(3 \cdot 51-6 \cdot 74) \\
(42 \cdot 1-395) \\
(0.12-3 \cdot 46) \\
(0.02-4 \cdot 80)\end{array}$ \\
\hline Others & 4 & 0.63 & $(0 \cdot 17-1 \cdot 62)$ & 1 & 0.79 & $(0.02-4 \cdot 42)$ & 5 & 0.67 & $(0 \cdot 21-1 \cdot 54)$ \\
\hline
\end{tabular}

Table 4 Observed (Obs) numbers of cancer cases and standardised incidence ratios (SIRs) with 95\% confidence intervals (95\% CIs) among 167 female anthophyllite asbestos miners in 1953-91 with at least three months of exposed time, by level of exposure

\begin{tabular}{|c|c|c|c|c|c|c|c|c|c|}
\hline \multirow[b]{3}{*}{ Primary site } & \multicolumn{9}{|c|}{ Exposure } \\
\hline & \multicolumn{3}{|c|}{ Heavy $(n=98)$} & \multicolumn{3}{|c|}{ Moderate $(n=69)$} & \multicolumn{3}{|c|}{ Total $(n=167)$} \\
\hline & $O b s$ & $S I R$ & $(95 \% C I)$ & Obs & SIR & $(95 \% C I)$ & Obs & $S I R$ & $(95 \% C I)$ \\
\hline All sites & 16 & 1.49 & $(0 \cdot 85-2 \cdot 42)$ & 7 & 1.02 & $(0 \cdot 41-2 \cdot 10)$ & 23 & $1 \cdot 31$ & $(0.83-1.96)$ \\
\hline $\begin{array}{l}\text { Oesophagus } \\
\text { Stomach } \\
\text { Colon } \\
\text { Rectum } \\
\text { Larynx } \\
\text { Lung } \\
\text { Mesothelioma } \\
\text { Breast } \\
\text { Cervix uteri } \\
\text { Corpus uteri } \\
\text { Ovary } \\
\text { Bladder }\end{array}$ & $\begin{array}{l}- \\
\overline{2} \\
1 \\
-1 \\
-1 \\
1 \\
5 \\
-\end{array}$ & $\begin{array}{l}\exp 0.23 \\
\exp 0.97 \\
3.66 \\
2.39 \\
\exp 0.02 \\
3.58 \\
\exp 0.01 \\
0.42 \\
1.69 \\
6.77 \\
\exp 0.68 \\
\exp 0.16\end{array}$ & $\begin{array}{l}(0 \cdot 00-16 \cdot 1) \\
(0 \cdot 00-3 \cdot 81) \\
(0 \cdot 44-13 \cdot 2) \\
(0 \cdot 06-13 \cdot 3) \\
(0 \cdot 00-207) \\
(0 \cdot 09-20 \cdot 0) \\
(0 \cdot 00-398) \\
(0 \cdot 01-2 \cdot 36) \\
(0 \cdot 04-9 \cdot 40) \\
(2 \cdot 20-15 \cdot 8) \\
(0 \cdot 00-5 \cdot 42) \\
(0 \cdot 00-23 \cdot 3)\end{array}$ & $\begin{array}{l}1 \\
1 \\
1 \\
- \\
\overline{-} \\
2 \\
1 \\
1 \\
-\end{array}$ & $\begin{array}{l}8.68 \\
1 \cdot 89 \\
3 \cdot 14 \\
\exp 0.24 \\
\exp 0.01 \\
\exp 0.17 \\
\exp 0.00 \\
1.16 \\
2.92 \\
2.04 \\
\exp 0.46 \\
\exp 0.09\end{array}$ & $\begin{array}{l}(0 \cdot 22-48 \cdot 4) \\
(0 \cdot 05-10 \cdot 5) \\
(0 \cdot 08-3 \cdot 14) \\
(0 \cdot 00-15 \cdot 2) \\
(0 \cdot 00-339) \\
(0 \cdot 00-21 \cdot 1) \\
(0 \cdot 00-551) \\
(0 \cdot 14-4 \cdot 18) \\
(0 \cdot 07-16 \cdot 3) \\
(0 \cdot 05-11 \cdot 4) \\
(0 \cdot 00-7 \cdot 99) \\
(0 \cdot 00-40 \cdot 5)\end{array}$ & $\begin{array}{l}1 \\
1 \\
3 \\
1 \\
-1 \\
-3 \\
2 \\
6 \\
-\end{array}$ & $\begin{array}{l}2.86 \\
0.67 \\
3.45 \\
1.52 \\
\exp 0.03 \\
2 \cdot 22 \\
\exp 0.02 \\
0.74 \\
2.15 \\
4.88 \\
\exp 1 \cdot 14 \\
\exp 0.25\end{array}$ & $\begin{array}{l}(0.07-15 \cdot 9) \\
(0.02-3 \cdot 71) \\
(0 \cdot 71-10 \cdot 1) \\
(0 \cdot 04-8 \cdot 44) \\
(0.00-123) \\
(0 \cdot 06-12 \cdot 4) \\
(0.00-190) \\
(0 \cdot 15-2 \cdot 15) \\
(0 \cdot 26-7 \cdot 77) \\
(1 \cdot 79-10 \cdot 6) \\
(0.00-3 \cdot 24) \\
(0.00-14 \cdot 8)\end{array}$ \\
\hline Others & 5 & $0 \cdot 71$ & $(0 \cdot 23-1 \cdot 66)$ & - & $\exp 4.50$ & $(0.00-0.82)$ & 5 & 0.43 & $(0 \cdot 14-1 \cdot 01)$ \\
\hline
\end{tabular}

Table 5 Observed (Obs) numbers of cancer cases, and standardised incidence ratios (SIRs) with 95\% confidence intervals (95\% CIs) among the 588 interviewed male anthophyllite asbestos miners in 1968-91 with at least three months of exposed time, by level of exposure and smoking (cigarettes/day)

\begin{tabular}{|c|c|c|c|c|c|c|c|c|c|}
\hline \multirow{3}{*}{$\begin{array}{l}\text { Primary site } \\
\text { and smoking }\end{array}$} & \multicolumn{9}{|c|}{ Exposure } \\
\hline & \multicolumn{3}{|c|}{ Heavy $(n=398)$} & \multicolumn{3}{|c|}{ Moderate $(n=200)$} & \multicolumn{3}{|c|}{ Total $(n=598)$} \\
\hline & Obs & SIR & $(95 \% C I)$ & Obs & $S I R$ & (95\% CI) & Obs & SIR & $(95 \% C I)$ \\
\hline $\begin{array}{c}\text { All sites: } \\
\text { No } \\
1-15 \\
\geqslant 16 \\
\text { Total }\end{array}$ & $\begin{array}{r}3 \\
33 \\
30 \\
66\end{array}$ & $\begin{array}{l}0.45 \\
1.55 \\
2 \cdot 28 \\
1.57\end{array}$ & $\begin{array}{l}(0 \cdot 09-1 \cdot 31) \\
(1 \cdot 04-2 \cdot 11) \\
(1 \cdot 54-3 \cdot 26) \\
(1 \cdot 22-2 \cdot 00)\end{array}$ & $\begin{array}{r}2 \\
14 \\
10 \\
26\end{array}$ & $\begin{array}{l}0 \cdot 34 \\
1 \cdot 82 \\
1 \cdot 80 \\
1 \cdot 36\end{array}$ & $\begin{array}{l}(0.04-1 \cdot 22) \\
(1.00-3.05) \\
(0.86-3.31) \\
(0.89-1.99)\end{array}$ & $\begin{array}{r}5 \\
48 \\
40 \\
92\end{array}$ & $\begin{array}{l}0.40 \\
1 \cdot 60 \\
2 \cdot 14 \\
1 \cdot 51\end{array}$ & $\begin{array}{l}(0.13-0.93) \\
(1 \cdot 19-2 \cdot 13) \\
(1 \cdot 53-2.92) \\
(1 \cdot 21-1 \cdot 84)\end{array}$ \\
\hline $\begin{array}{l}\text { Lung: } \\
\text { No } \\
1-15 \\
\geqslant 16 \\
\text { Total }\end{array}$ & $\begin{array}{r}1 \\
20 \\
21 \\
42\end{array}$ & $\begin{array}{l}0 \cdot 48 \\
2 \cdot 79 \\
4 \cdot 91 \\
3 \cdot 15\end{array}$ & $\begin{array}{l}(0 \cdot 01-2 \cdot 64) \\
(1 \cdot 70-4 \cdot 30) \\
(3 \cdot 04-7 \cdot 50) \\
(2 \cdot 28-4 \cdot 24)\end{array}$ & $\begin{array}{r}1 \\
4 \\
8 \\
13\end{array}$ & $\begin{array}{l}0 \cdot 58 \\
2 \cdot 65 \\
4 \cdot 49 \\
2 \cdot 18\end{array}$ & $\begin{array}{l}(0 \cdot 01-3 \cdot 21) \\
(0.45-4 \cdot 21) \\
(1 \cdot 94-8 \cdot 84) \\
(1 \cdot 16-3 \cdot 73)\end{array}$ & $\begin{array}{r}2 \\
25 \\
29 \\
55\end{array}$ & $\begin{array}{l}0 \cdot 52 \\
2 \cdot 60 \\
4 \cdot 79 \\
2 \cdot 79\end{array}$ & $\begin{array}{l}(0 \cdot 06-1 \cdot 88) \\
(1 \cdot 68-3 \cdot 83) \\
(3 \cdot 21-6 \cdot 87) \\
(2 \cdot 10-3 \cdot 63)\end{array}$ \\
\hline $\begin{array}{l}\text { Mesothelioma } \\
\text { No } \\
1-15 \\
\geqslant 16 \\
\text { Total }\end{array}$ & $\frac{-}{4}$ & $\begin{array}{l}\exp 0.01 \\
146 \\
\exp 0.02 \\
69.0\end{array}$ & $\begin{array}{c}(0 \cdot 00-395) \\
(39 \cdot 9-374) \\
(0 \cdot 00-188) \\
(18 \cdot 8-177)\end{array}$ & $\frac{-}{-}$ & $\begin{array}{l}\exp 0.01 \\
\exp 0.01 \\
\exp 0.00 \\
\exp 0.03\end{array}$ & $\begin{array}{l}(0.00-389) \\
(0.00-409) \\
(0.00-517) \\
(0.00-134)\end{array}$ & $\frac{-}{4}$ & $\begin{array}{l}\exp 0.02 \\
99 \cdot 7 \\
\exp 0.02 \\
44 \cdot 2\end{array}$ & $\begin{array}{l}(0 \cdot 00-196) \\
(27 \cdot 2-256) \\
(0 \cdot 00-180) \\
(12 \cdot 1-114)\end{array}$ \\
\hline $\begin{array}{l}\text { Other cancers: } \\
\text { No } \\
1-15 \\
\geqslant 16 \\
\text { Total }\end{array}$ & $\begin{array}{r}2 \\
9 \\
9 \\
20\end{array}$ & $\begin{array}{l}0.43 \\
0.61 \\
1.02 \\
0.71\end{array}$ & $\begin{array}{l}(0.05-1.55) \\
(0.28-1.16) \\
(0.47-1.94) \\
(0.43-1.10)\end{array}$ & $\begin{array}{r}1 \\
10 \\
2 \\
13\end{array}$ & $\begin{array}{l}0.23 \\
1.91 \\
0.53 \\
0.97\end{array}$ & $\begin{array}{l}(0.01-1.28) \\
(0.92-3.51) \\
(0.06-1.92) \\
(0.52-1.67)\end{array}$ & $\begin{array}{r}3 \\
19 \\
11 \\
33\end{array}$ & $\begin{array}{l}0.33 \\
0.95 \\
0 \cdot 87 \\
0.79\end{array}$ & $\begin{array}{l}(0.07-0.98) \\
(0.57-1.49) \\
(0.44-1.56) \\
(0.55-1.12)\end{array}$ \\
\hline
\end{tabular}


Standardised incidence ratios (SIRs) of lung cancer (with 95\% CIs) among male anthophylite asbestos exposure: by duration of exposure and smoking.

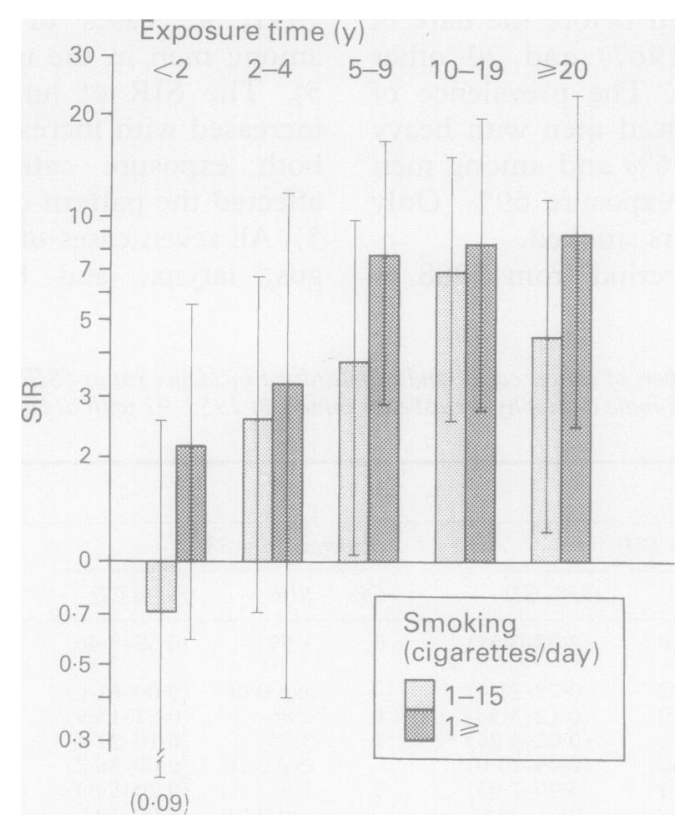

among smokers and all four cases of mesothelioma were among heavily exposed men who smoked.

The SIR of lung cancer among the heavily exposed men strongly increased with increasing duration of exposure up to about 20 years (figure). In the moderately exposed group there seemed to be no such trend.

Among the interviewed 86 women classified as heavily exposed 14 cases of cancer were observed $v 7.8$ expected. A significant excess of endometrial cancer was observed among heavily exposed non-smokers.

\section{Discussion}

The cohort consisted of all workers with at least three months of employment in the two anthophyllite asbestos mines in the heart of Finland. The identification and follow up for deaths and emigration are complete for the period of this study, 1953-91. Also the cancer registration system in Finland is virtually complete ${ }^{11}$ and the computerised record linkage procedures are accurate. The potential problems - if any-are in manual linkagethat is, they concern those who have died before 1 January 1967. The workers of this cohort resemble in many aspects the average population of eastern mid-Finland used as the reference population of this study.

In a study based on the record linkage between the Finnish Cancer Registry and the population census of 1970 , a standardised incidence ratio of $2.1 \quad(p<0.001)$ for total cancer was found in 35-69 year old men in mining and quarrying in Finland during the period $1971-5,12$ a similar excess seemed to continue into later periods. ${ }^{13}$

The incidence of lung cancer clearly increased with smoking but did not depend much on the level of asbestos exposure (heavy or moderate). The SIR increased, however, with the duration of asbestos exposure. The reference population also includes smokers. In the early 1960 s some $60 \%$ of Finnish men smoked. ${ }^{14}$ This means that the SIRs for, for example, lung cancer obtained for smokers, should be multiplied by a factor of at least three (given that one half of the population are smokers and thus have a fivefold $R R$ of lung cancer in comparison with non-smokers) if a comparison with a nonsmoking non-exposed population is required. In that case the risk estimates of Meurman and coworkers ${ }^{7}$ still seem to be valid. Among Danish asbestos cement workers exposed to mixed types of asbestos the highest RR (3.3) was for adenocarcinoma; the risk for all other histological types of lung cancer was about $1 \cdot 6 .^{15}$ Our results suggest the opposite risk pattern, or maybe no difference at all by histological type.

All the four cases of mesothelioma were among men who had been heavily exposed for 13-31 years and who also smoked. The time from the first employment to the detection of mesothelioma was long (39-53 years). Mesothelioma cases are rare in Finland: for the whole reference area with a population of 0.9 million, 47 cases of mesothelioma were registered in 1982-91. This corresponds to an age adjusted (world standard) incidence of $0 \cdot 4 / 10^{5}$ both in males and in females. The liability of the reference incidence in the case of mesothelioma makes the estimation of real SIR more unstable than in the case of other sites analysed here. The RR for mesothelioma among asbestos workers, however, seems to be several orders of magnitude higher than that of the Finnish average.

The numbers of other types of cancer were so small that no clear conclusions can be drawn. The only significantly increased SIR-besides the SIRs of lung cancer and mesothelioma-was the $6 \cdot 8$-fold risk $(95 \% \mathrm{CI}$ $2 \cdot 2-16)$ for cancer of the corpus uteri. This association has not been reported in any earlier study and there are no biological mechanisms known to account for asbestos exposure and risk of this cancer.

Although all types of asbestos cause asbestosis and lung cancer, the differences in the mechanisms of different types of asbestos are not well known. In animal tests it has been proved that all types of asbestos, including anthophyllite, can cause mesothelioma. ${ }^{16}$ Therefore it was expected that there would be mesothelioma also among anthophyllite miners.

The chemical composition varies between the different types of asbestos and only the fibrous structure is common for all the types. Therefore it is likely that the carcinogenic properties of different asbestos types depend on the fibre structure. Chrysotile asbestos is spiral and tubular whereas the amphibolic types are straight and not hollow. Instead, the thickness of the fibres is systematically different between the amphibolic asbestoses. Anthophyllite asbestos is more crude than crocidolite asbestos. The potential to cause pulmonary fibrosis depends on the surface area of the fibre, and not on the aspect ratio. ${ }^{17}$ Therefore, the potential of crocidolite to 
cause fibrosis is higher than that of the anthophyllite asbestos. Assuming that the carcinogenic potential and fibrogenic potential are correlated, the surface area of fibre should also be related to the carcinogenic potential of the asbestos type.

Most of the earlier studies suggest that crocidolite and amosite asbestos would be more strongly associated with causation of lung cancer than chrysotile or anthophyllite. ${ }^{218}$ The results for asbestos factory workers differ from the results for asbestos miners. It is suggested that the "textile anomaly"19 is caused by the mineral oil spray used for eliminating dust in factories that is contaminated with asbestos fibres. Workers in a factory that had used only amosite asbestos experienced an SMR of 5.4 for lung cancer ${ }^{20}$ whereas the SMR among white male miners of amosite mines in South Africa was only $1 \cdot 4 .^{5} \mathrm{We}$ found an SIR of 2.9 for lung cancer among anthophyllite asbestos miners (anthophyllite seems to have a stronger effect on lung cancer than amosite). In comparison with crocidolite miners in Western Australia (141 lung cancers among 1350 deaths) ${ }^{4}$ our results showed a slightly higher proportion of deaths from lung cancer (76/593 deaths).

A detailed study of chrysotile asbestos miners ${ }^{1}$ revealed only a moderate risk of lung cancer; the SMR of the miners with at least one year of exposed time did not exceed 1.3 even with the longest follow up times. Comparison of the studies of risk of lung cancer for miners of different types of asbestos is difficult because of inconsistencies in study materials. The follow up times vary, dust concentrations were not systemically measured in earlier times, smoking habits, and exact information about the nature of the job and about the exposed time are often not known.

Comparison of mesothelioma risk associated with different types of asbestos is easier as smoking has no role in the cause of mesothelioma. The moderate excess of mesothelioma among chrysotile miners may not in every case be caused by chrysotile asbestos itself but by the fibrous tremolite found in small quantities among the chrysotile mine dust. $^{32122}$ The fibre analysis of the Finnish anthophyllite asbestos miners' lungs did not show tremolite, ${ }^{23}$ so the four cases of mesothelioma in our study are likely to be caused by anthophyllite. The frequency of mesotheliomas (four among 736 men, corresponding to an incidence of $23 / 10^{5}$ after a lag of 10 years) in our cohort was much lower, however, than that among crocidolite miners in Australia ${ }^{4}$ or in South Africa. ${ }^{5}$ The relative risk of mesothelioma associated with amosite asbestos has been estimated to be between the risks caused by anthophyllite and crocidolite. ${ }^{2}$ The number of mesotheliomas in our anthophyllite mines cohort, however, equals the number of mesotheliomas in an amosite asbestos miner cohort in South Africa with an almost identical number of deaths. ${ }^{5}$
Our results indicate that anthophyllite is a more potent carcinogen for lung cancer than chrysotile and amosite and is almost as potent as crocidolite. The number of mesothelioma cases was small and the risk lower than among crocidolite miners, almost as high as among amosite miners but higher than among chrysotile miners.

1 McDonald JC, Liddell FDK, Gibbs GW, Elyssen GE, McDonald AD. Dust exposure and mortality in chrysotile mining. Br F Ind Med 1980;37:11-24.

2 UK Advisory Committee on asbestos: final report of the Advisory Committee. Vol II. Papers prepared for the Advisory Committee. 1 Asbestos-Great Britain safety measures. London: HMSO, 1979.

3 Churg A, Wiggs B, Depaoli L, Kampe B, Stevens B. Lung asbestos content in chrysotile workers with mesothelioma. Am Rev Respir Dis 1984;130:1042-5.

4 De Klerk NH, Armstrong BK, Musk AW, Hobbs MST. Predictions of future cases of asbestos-related disease among former miners and millers of crocidolite in among former miners and millers of crocidolite

5 Sluis-Cremer GK, Liddell FDK, Logan WPD, Bezuidenhout BN. The mortality of amphibole miners in South Africa, 1946-80. Br $\mathcal{F}$ Ind Med 1992;49: 566-75.

6 Huuskonen MS, Ahlman K, Mattson T, Tossavainen A. Asbestos disease in Finland. $\mathcal{F}$ Occup Med 1980;22 $751-4$.

7 Meurman LO, Kiviluoto R, Hakama M. Mortality and morbidity among the working population of anthophyllite asbestos miners in Finland. $B r \mathcal{F}$ Ind Med 1974; 31:105-12.

8 Meurman LO, Kiviluoto R, Hakama M. Combined effects of asbestos and tobacco smoking on Finnish anthophyllite miners and millers. Ann NY Acad $S c i$ 1979;330:491-5.

9 Tuomi T, Segerberg-Konttinen $M$, Tammilehto L, Tossavainen A. Mineral fibre concentration in lung tissue of mesothelioma patients in Finland. Am $\mathcal{F}$ Ind Med 1989;16:247-54.

10 Tuomi T. Fibrous minerals in the lungs of mesothelioma patients: comparison between data on SEM, TEM and personal interview information. Am $\mathcal{F}$ Ind Med 1992; 21:155-62.

11 Saxen E, Teppo L. Finnish Cancer Registry 1952-1977. Twenty-five years of nationwide cancer registry. Helsinki: Twenty-five years of nationwide
Finnish Cancer Registry, 1978.

12 Pukkala E, Teppo L, Hakulinen T, Rimpelä $M$ Occupation and smoking as risk determinants of lung cancer. Int $\mathcal{F}$ Epidemiol 1983;12:290-6.

13 Pukkala E. Use of record linkage in small-area studies. In: Elliot P, Guzick J, English D, Stern R, eds. Geographical and environmental epidemiology. Oxford: Oxford University Press, 1992:125-31.

14 Rimpelä M. Adult use of tobacco in Finland in the 1950s to 1970s. The state of smoking in autumn 1976, changes in cigarette smoking in 1968-1976 and conclusions of developcigarette smoking in 1968-1976 and conclusions of development of smoking habits (in Finnish). Tampere: Department of Public Health, University of Tampe
1978. (Publication of Public Health 17 M 40/78).

15 Raffn E, Lynge E, Korsgaard B. Incidence of lung cancer by histological type among asbestos cement workers in by histological type among asbestos cem
Denmark. $\mathrm{Br} \mathcal{F}$ Ind Med 1993;50:85-9.

16 Wagner JC, Berry G, Skidmore JW, Timbrell V. The effect on inhalation of asbestos in rats. $\mathrm{Br} \mathcal{F}$ Cancer 1974;29:252-69.

17 Timbrell V, Ashcroft T, Goldstein B, Heyworth F, Meurman LO, Rendall REG, Reynolds JA, Shilkin KB, Whitaker D. Relationship between retained amphibole fibres and fibrosis in human lung tissue specimens. Ann Occup Hyg 1988;32(suppl 1):323-40.

18 Henderson VL, Enterline PE. Asbestos exposure: factors associated with excess cancer and respiratory disease associated with excess cancer and respiratory
mortality. Ann NY Acad Sci 1979;330:117-26.

19 McDonald JC. Cancer risks due to asbestos and man made fibres. Recent results in cancer research. In: Band $\mathrm{P}$, ed. Occupational cancer epidemiology. Berlin: SpringerVerlag, 1990;120:122-31.

20 Seidman H, Selikoff IJ, Gelb SK. Mortality experience of amosite asbestos factory workers: dose response relationship 5 to 40 years after onset of short-term work exposure. Am F Ind Med 1986;10:479-514.

21 McDonald JC, Armstrong B, Case B, Doell D McCaughey WTE, McDonald AD, Sébastien P. Mesothelioma and asbestos fibre type. Evidence of lung cancer tissue analyses. Cancer 1989;63:1544-7.

22 Dement JM. Carcinogenicity of chrysotile asbestos: evidence from cohort studies. Ann NY Acad Sci 1991;643: 15-23.

23 Karjalainen A, Meurman L, Pukkala E. Four cases of mesothelioma among Finnish anthophyllite miners. Occup Environ Med 1994;51:212-5. 